\title{
Research on systematization and advancement of shipbuilding production management for flexible and agile response for high value offshore platform
}

\author{
Young-Joo Song ${ }^{1}$, Jong-Hun Woo ${ }^{1}$ and Jong-Gye Shin $^{2}$ \\ ${ }^{I}$ Samsung SDS, Korea \\ ${ }^{2}$ Department of Naval Architect and Ocean Engineering, Seoul National University, Seoul, Korea
}

\begin{abstract}
Recently, the speed of change related with enterprise management is getting faster than ever owing to the competition among companies, technique diffusion, shortening of product lifecycle, excessive supply of market. For the example, the compliance condition (such as delivery date, product quality, etc.) from the ship owner is getting complicated and the needs for the new product such as FPSO, FSRU are coming to fore. This paradigm shift emphasize the rapid response rather than the competitive price, flexibility and agility rather than effective and optimal perspective for the domestic shipbuilding company. So, domestic shipbuilding companies have to secure agile and flexible ship production environment that could respond change of market and requirements of customers in order to continue a competitive edge in the world market.

In this paper, I'm going to define a standard shipbuilding production management system by investigating the environment of domestic major shipbuilding companies. Also, I'm going to propose a unified ship production management and system for the operation of unified management through detail analysis of the activities and the data flow of ship production management. And, the system functions for the strategic approach of ship production management are investigated through the business administration tools such as performance pyramid, VDT and BSC. Lastly, the research of applying strategic KPI to the digital shipyard as virtual execution platform is conducted.
\end{abstract}

KEY WORDS: Ship; Offshore structure; FPSO; FSRU; Platform; Shipbuilding; Production; Management; Knowledge; Simulation; BSC; VDT.

\section{NOMENCLATURE}

$\begin{array}{ll}\text { BSC } & \text { : Balanced Score Card } \\ \text { CAD } & \text { : Computer Aided Design } \\ \text { CSF } & \text { : Critical Success Factor } \\ \text { DES } & \text { : Discrete Event System } \\ \text { FPSO } & \text { : Floating Production and Storage Offshore } \\ \text { FSRU } & \text { : Floating Storage and Retrieval Unit } \\ \text { KPI } & \text { : Key Performance Index } \\ \text { M\&S } & \text { : Modeling \& Simulation } \\ \text { PDQC } & \text { : Productivity, Delivery, Quality, Cost } \\ \text { PDCF } & \text { : Productivity, Delivery, Cost, Flexibility } \\ \text { PLM } & \text { : Production Lifecycle Management } \\ \text { PPRS } & \text { : Product, Process, Resource and Schedule } \\ \text { VDT } & \text { : Value Driver Tree }\end{array}$

\section{INTRODUCTION}

Recently, the speed of change related with enterprise

Corresponding author: Jong-Hun Woo

e-mail: jonghun_woo@naver.com management is getting faster than ever owing to the competition among companies, technique diffusion, shortening of product lifecycle, excessive supply of market. Also, most enterprises are facing strong pressure of developing new products and services that can satisfy the sensitive needs of customers (Lee, 2007). These changes of enterprise circumstances could be explained as transition of competitiveness paradigm. This paradigm shift emphasize the rapid response rather than the competitive price, flexibility and agility rather than effective and optimal perspective. (Betsy, 2006; Jack and Suzy, 2005).

This paradigm shift could be observed in the shipbuilding industry, which has been conservative comparing with other industries such as automotive or consumer goods. The compliance condition (such as delivery date, product quality, etc.) from the ship owner is getting complicated and the needs for the new product such as FPSO, FSRU are coming to fore. Also, the extrinsic factor such as a brand value of enterprise is getting important setting aside a quality and price competitiveness, and environment and safety factors are becoming hard to satisfy customer requirements. Consequently, the strategic survival and surpass strategy come into the picture owing to 
the speed-up of shipbuilding industry circumstances changes.

In this paradigm shift, domestic shipbuilding companies have to secure agile and flexible ship production environment that could respond change of market and requirements of customers in order to continue a competitive edge in the world market. In this paper, I'm going to define a standard shipbuilding production management system by investigating the environment of domestic major shipbuilding companies. Also, I'm going to propose a unified ship production management and system for the operation of unified management through detail analysis of the activities and the data flow of ship production management. The object of is to secure the flexible and agile management system for the ship production. The flexible and agile production management could contribute the reduction of investment cost for change of shipbuilding environment and respond quickly to the various requirements of customers. Also, this agile management enables an increase of ship production by reducing decision-making and shipbuilding lead time.

Next, the system functions for the strategic approach of ship production management are investigated through the business administration tools such as performance pyramid, Value Driver Tree (VDT) and Balanced Score Card (BSC). Derived functions act as a knowledge requisite of the ship production management system, and enable the integrated production management by composing information liking the multi-level objectives such as a delivery observance, a cost reduction, etc.

Lastly, I have introduced a practice of applying KPI analysis of BSC to the digital shipyard as virtual execution platform. The required functions the implementation of virtual platform are linked systemically.

\section{PREVIOUS RESEARCH REVIEW}

\section{Review of Shipbuilding Production Management}

Production management system of shipbuilding is a kind of supporting tool for the purpose of management w.r.t. complicated and heavy structure information, and for the planning and control w.r.t. sophisticated and wide range of shipbuilding processes and activities. Most production management systems of domestic shipbuilding companies have been being developed by their own companies because the production circumstances are different respectively. It means that there have been no standard definitions about ship production management and its system. Current production management systems have been being developed reflecting company's characteristics of its own circumstances. Problem is that there systems are developed with bottom-up approach without establishment of overall system architecture and its function \& algorithm. This problem has caused an internally entangled system and also system is becoming more complex as additional functions or algorithms are attached. As a result, even major shipbuilding companies of Korea are having difficulties in development and maintenance of ship production management system, and this cause weak react ability in the varying internal and external conditions of shipbuilding companies.

\section{Review on Performance Management}

Theories of manufacturing performance management have been being developed for the purpose of realization of competitive paradigm and, purpose of proposing of reasonable performance measuring method. The recent theories after 1980 have overcome a limitation of traditional finance-oriented enterprise evaluation, and expand the boundary up to non-financial aspect.

Meanwhile, the theory of performance management in manufacturing field is being developed in the direction of the supporting of competitiveness paradigm realization and also, the proposing of reasonable performance measuring methodologies. Especially, the theories about the manufacturing performance management have been developed in the direction of expanding non-financial performance index beyond the previous financial oriented approach, which can be found is an induction of long time performance evaluation (Banks and Wheel, 1979), a shortage of strategic focus (Skinner, 1974), an induction of local optimization (Goldraff and Cox, 1986), etc. Also, the research after 1990's shows a trend of emphasizing a strategic enterprise administration and a strategic evaluation method by merging the theory of the performance management into the previous theory of the enterprise survival management. In this movement, the researches about the problem of the traditional financial performance evaluation system (Dixon et al., 1990; Kaplan and Norton, 1992) and the direction of the future result evaluation system (Park, 1997) are conducted. Related research with can be found at the performance measurement innovations (Ittner and Larcker, 1998) or the performance measurement revolution (Neely, 1999). Especially, Skinner laid a special emphasis on the importance of Productivity, Delivery, Quality, Control (PDQC) ideology of Skinner $(1971,1974)$ is moving to the Quality, Delivery, Control, Flexibility (QDCF) ideology of Neely (1995), where recent enterprise competitiveness index has big portion of flexibility.

\section{Review on Simulation Based Shipbuilding Support}

From 2001 to 2004, the nationally funded 'Integrated Digital Shipbuilding Technology for Development of High Value-added Ship' project was conducted by a consortium consisting of Seoul National University, Samsung Heavy Industries, and several national institutes. Through this project, research on ship production and shipbuilding simulation was widely performed. Several practices for the shipyard forecasting system were performed by the modeling of the product, process, resource and planning data into an integrated simulation model. Woo have conducted a construction framework for digital shipyard from this project (2005). 
Frensberg shipyard of Germany has been conducting a research for the simulation project for application to the shop floor since 2003 and Simulation Toolkit for Shipbuilding (STS) was developed as a result of the project. There came out a practice for the fabrication process (Kaarsemaker et al., 2006), and one for the block assembly process planning system (Steinhauer and Stephanie, 2006). These kinds of researches have their own significance in focusing on the advancement of planning and prediction capability with the application to the actual ship production environment apart from traditional simulation approach.

There came out a systematic shipyard layout design framework with the increase of the new business of shipyard construction since the early part of 2000s. In the past, traditional method was to perform benchmark from the existing shipyard layout. However, try-out or trial and error method was at last worn out. Song have developed shipyard layout design framework and adopted a simulation method for the enhancement of proposing framework in an effort to resolve the existing (or traditional) method (2008a, b). This research proposed a framework suit for the shipyard layout design, which overcame the traditional layout design methodology, and also this framework was embodied as an actual design system with the user interface. The proposing framework was also used for the preliminary layout design for the Indian Shipyard with the initial condition such as field data, target ship, and target throughput.

The status of maturity of virtual execution platform (such as factory simulation, etc.) as ship production environment, however, is still in the early stage because of the lack of ship production management information. So, the research of systematic ship production management has to be preceded for the adoption of innovative methodology.

\section{STANDARDIZATION AND UNIFICATION OF SHIP PRODUCTION MANAGEMENT SYSTEM}

In this chapter, I'm going to propose a unified ship production management system through the research of the domestic shipbuilding companies. The analysis target is domestic 3 major shipbuilding companies and the analysis result will be shown for D company.

\section{Defining of Ship Production Management System}

Production management is, generally, defined as processes for planning/tuning/control of production activities and actions for maximization of enterprise profit and competitiveness. The coverage scope of production management is divided into management of manufacturing behavior and management of enterprise administration such as enhancement of productivity, profitability, etc. Especially, the scope of production management is varying from factory oriented management to centering around enterprise strategic approach.
Production management for shipbuilding has to support a typical build-to-order characteristic and manage large scale of resources flexibly. Also, overall planning strategy and resource management have to be combined because the delivery date is very critical. The scope of ship production management is enterprise business administration as first, and management activities from order through design/production/procurement to delivery secondly, and production process management lastly. This production management aims at lead time reduction, cost reduction, on-time delivery, etc. by flexible and agile response to varying development $\&$ production environments.

Ship production management system for the above has to be constructed for the effective response with respect to the production and business administration environment, and eventually contribute to the benefit maximization. That is to say, the enterprise object is to secure sustainable competitiveness for earning benefit, so balanced production planning and scheduling, right-time procurement, accurate production management and optimized production method have to be guaranteed. Accordingly, the object of ship production management system is systematic management of planning and managing information and advancement of managing efficiency as a kind of management supporting system.

Through the research about the domestic major shipbuilding companies, I could structure the common domain and activities of ship production management system. In the point of shipbuilding, ship production management system could be organized as 5 macro domains and 16 managing activities though it can be differentiated at specific region w.r.t. each shipbuilding company. This organization is shown in Fig. 1. In this paper, I'm going to propose this organization as a standard ship production management system.

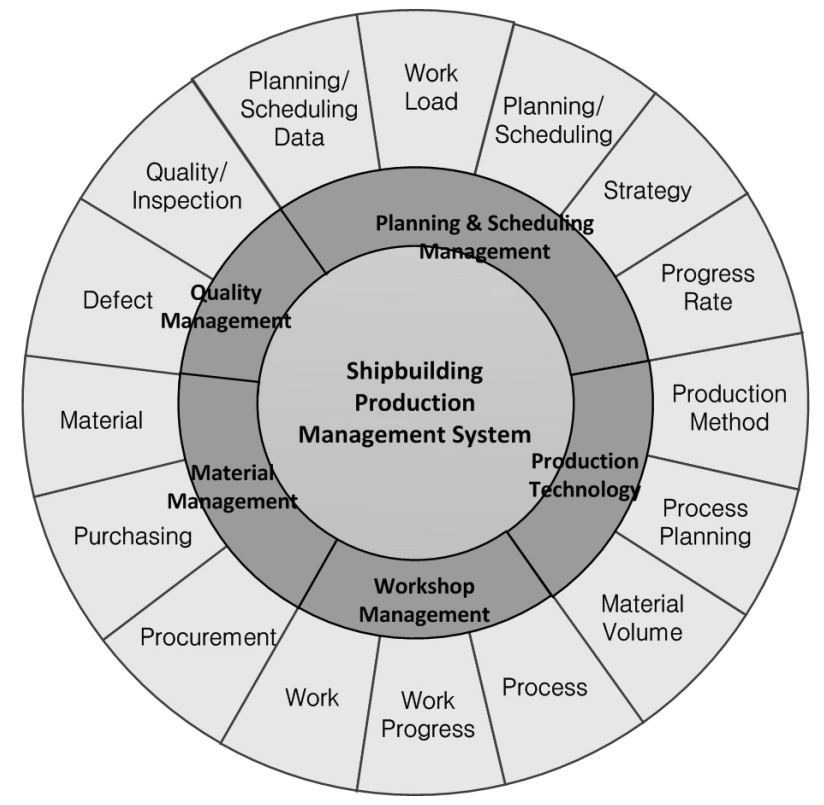

Fig. 1 Organization of standard ship production management system. 


\section{Analysis of Ship Production Management System}

Now, ship production management system is being gone into detail level through the analysis of two large size shipbuilding companies and one middle size shipbuilding company. The analysis is focused on the functions of system and data flow among each process and activities based on the standard ship production management system, finally propose a unified ship production management and ship production management system. In this paper, the analysis result is shown for one large size shipbuilding company owing to the space limitation.

Fig. 2 shows major functions of company D through the analysis of functions of ship production management system of company D and arrange those functions based on the major domain of production management. From this analysis, the data flow among each function (activities) is analyzed as shown in Fig. 3, which is detailed from Fig. 2. Also, functional structure and flow chart (Fig. 2 and Fig. 3) has consistency from standard ship production management system in Fig. 1, so the traceability of analysis could be got afterward.
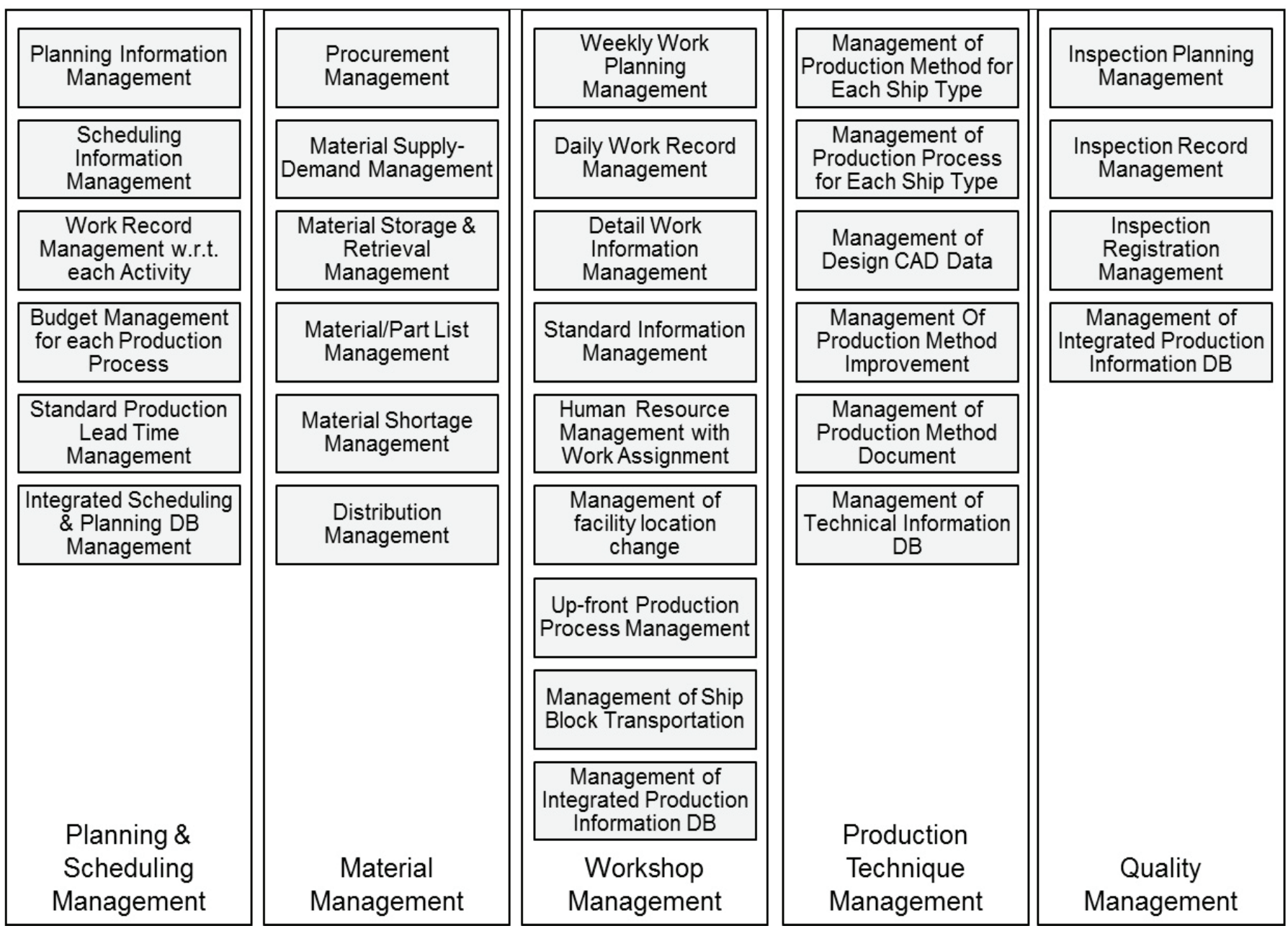

Fig. 2 Functional structure of ship production management system of large sized shipbuilding company D.

\section{Proposing of Unified and Systemized Ship Production Management}

In this chapter, unified ship production management and system will be proposed based on major enterprise business activity which mainly focused on production. This proposing model is derived from the analysis result of functional structure and activity data flow of 3 companies of foregoing chapter.

All the production management activities could be divided into planning activity and management activity, and structured along with production flow and object. Table 1 and Table 2 show description of planning activities and management activities respectively. Moreover, ship production management information could be mutually connected based on the relation proximity. Fig. 4 shows a behavioral structure of the ship production management along with the order of production and information generation based on the grouping of planning and management aspect. Here, each item is lined up considering management activities, objects and relevant system. Then, the construction of a unified ship production management system is designed based on ship production management (Fig. 4) as shown in Fig. 5, where each management activities and those object are connected with management functions. 


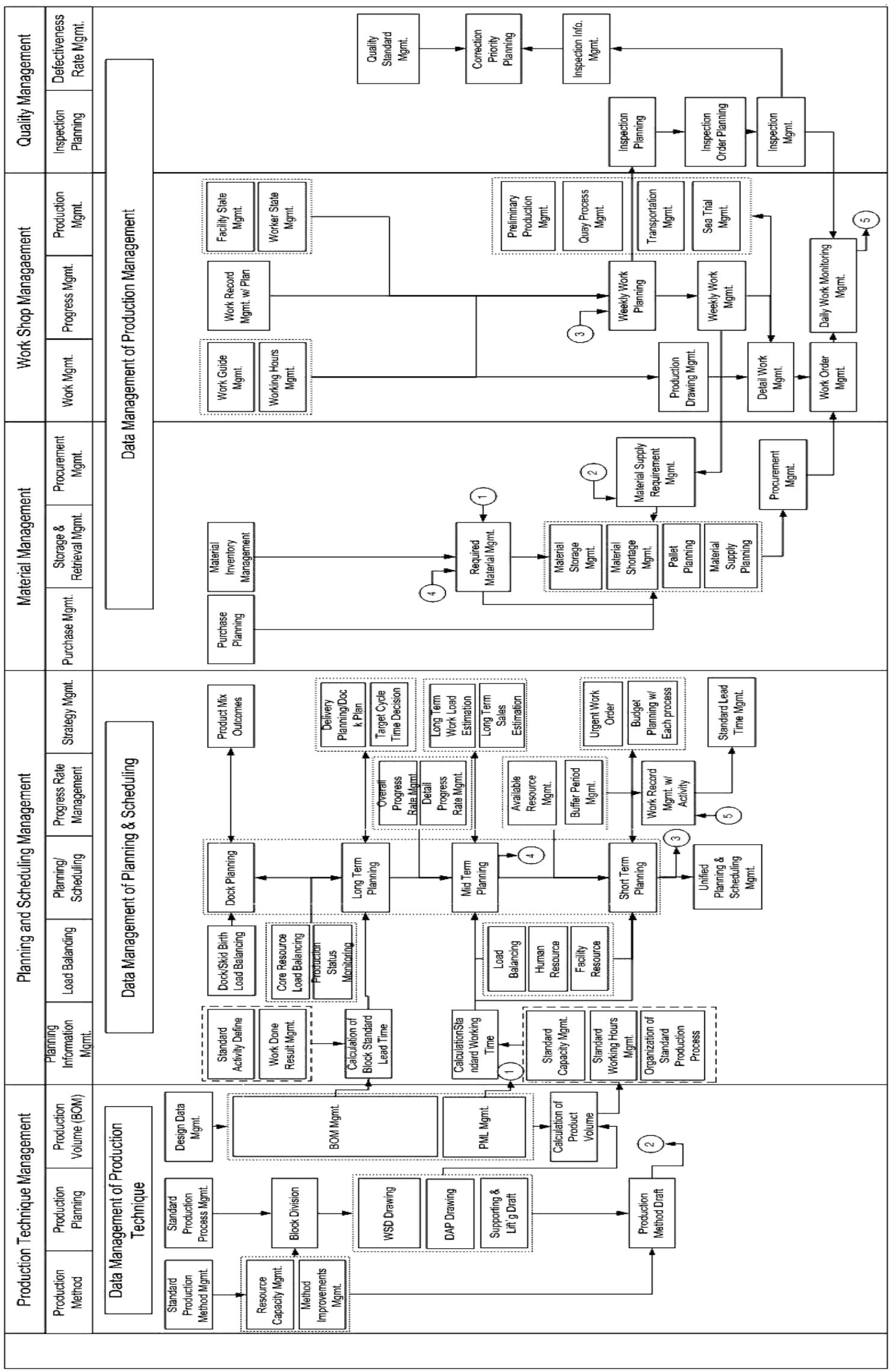

Fig. 3 Activity flow chart of the ship production management system of large sized ship company D. 
Table 1 Description of planning activities of shipbuilding.

\begin{tabular}{|c|l|}
\hline Major Activity & \multicolumn{1}{c|}{ Detail Activity Description } \\
\hline Facility & $\begin{array}{l}\text { - Facility planning is composed of factory layout and process layout (routing) and the production flow is } \\
\text { determined along with the production capacity based on the facility layout. }\end{array}$ \\
Planning & $\begin{array}{l}\text { - Facility utilization is to make a plan of facility assignment with process planning based on the secured } \\
\text { facility specifications. }\end{array}$ \\
\hline Process & $\begin{array}{l}\text { - Generate work order description by input of block design data. } \\
\text { - Production method is selected by process planning. }\end{array}$ \\
Planning & $\begin{array}{l}\text { - Determine the product flow sequence } \\
\text { - Determine the lead time of each production process by control of available resources and those capacity. }\end{array}$ \\
\hline Schedule & $\begin{array}{l}\text { - Make a plan of production strategy and material procurement with respect to the dock plan and long- } \\
\text { term planning (Capacity planning) }\end{array}$ \\
& $\begin{array}{l}\text { Make a mid-term and short-term schedule considering an available resource, a production volume of } \\
\text { each ship and an estimated man hour. }\end{array}$ \\
\hline
\end{tabular}

Table 2 Description of management activities of shipbuilding.

\begin{tabular}{|c|c|}
\hline Major Activity & Detail Activity Description \\
\hline $\begin{array}{c}\text { Facility } \\
\text { Management }\end{array}$ & $\begin{array}{l}\text { - Facility management is divided into a capacity management and a utilization management. } \\
\text { - Facility management includes maintenance activities. } \\
\text { - Facility information maintained by management activities is used as a standard data at process/schedule } \\
\text { planning. }\end{array}$ \\
\hline $\begin{array}{c}\text { Process } \\
\text { Management }\end{array}$ & $\begin{array}{l}\text { - Investigate the production method and the process planning in order to reflect the improvement plan at } \\
\text { the succeeding period. }\end{array}$ \\
\hline $\begin{array}{c}\text { Schedule } \\
\text { Management }\end{array}$ & $\begin{array}{l}\text { - Manage the production progress rate with respect to the planned schedule. } \\
\text { - Facility improvement plan and production method improvement plan is conducted according to the } \\
\text { production progress rate management. }\end{array}$ \\
\hline
\end{tabular}

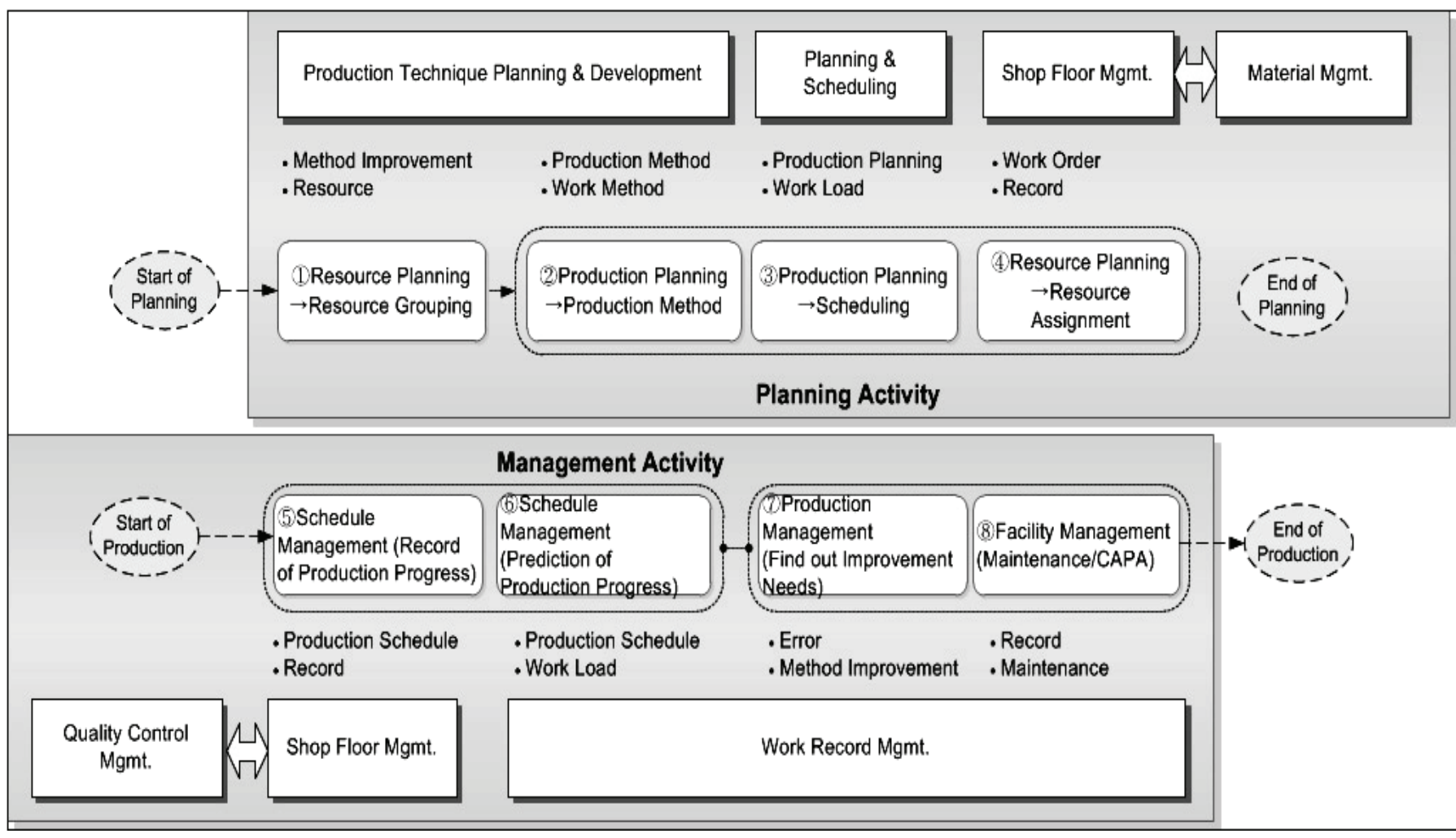

Fig. 4 Systemization of ship production management. 


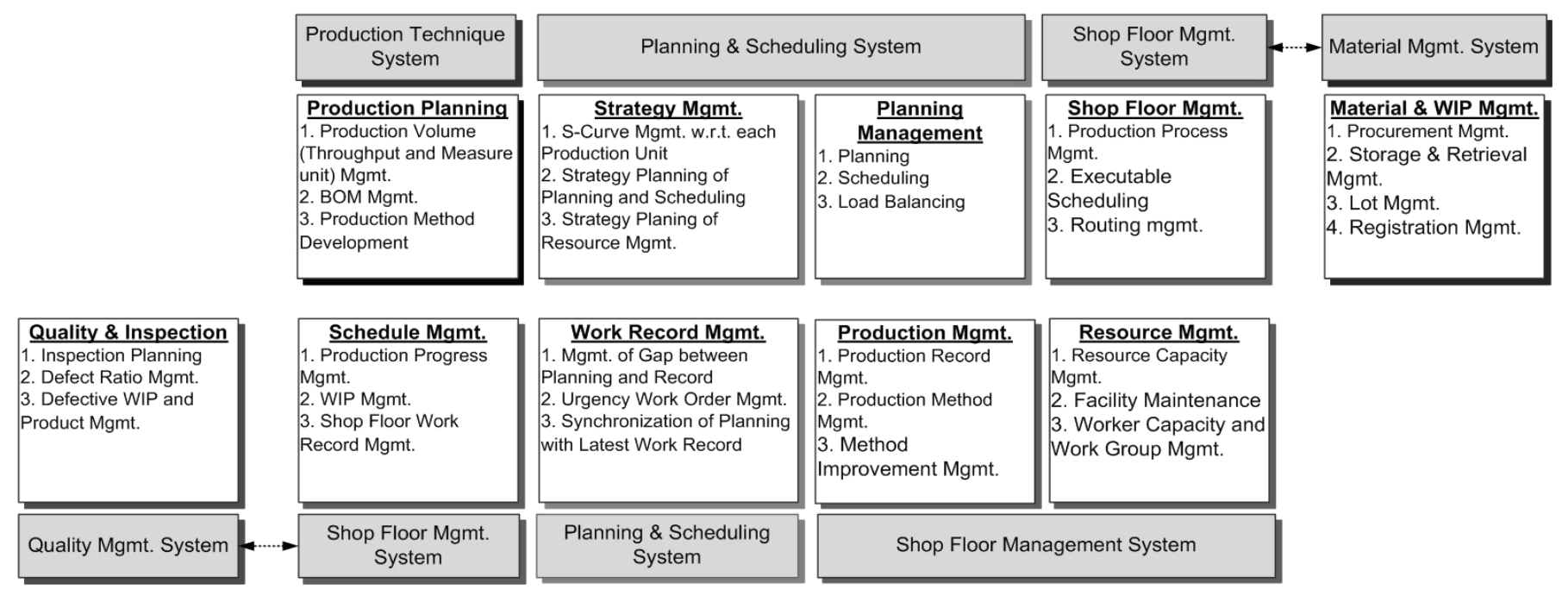

Fig. 5 Unification of ship production management system.

\section{ANALYSIS ON FUNCTIONAL ASPECTS OF SHIP PRODUCTION MANAGEMENT SYSTEM}

In this chapter, the functions for the strategic ship production management system are established for yard, factory, and process level considering the unified ship production management system that is previously defined. For this, several tools of business administration such as performance pyramid, VDT and BSC are used.

\section{Functional Strategy Analysis with Performance Pyramid}

The performance pyramid shown in Fig. 6 (Lynch and Cross, 1995) is composed of performance index in the view of business administration, business operation and department including the manufacturing competitiveness index (PDQD, QDCF). Also, this pyramid divides the performance index into the internal efficiency and the external efficiency. So, the performance pyramid has significances not only in the performance measuring but in the management system for the competitiveness security.

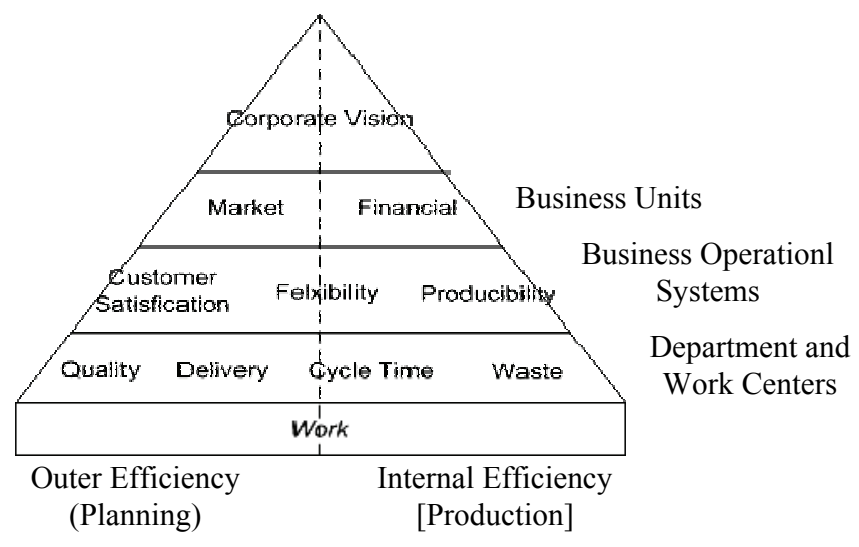

Fig. 6 Performance pyramid.
For this reason, performance pyramid, in this paper, is applied for the defining of the high measuring level of strategic ship production management. Fig. 7 shows a competitiveness index and relevant management items for the strategic ship production management. High measuring level is defined as yard, factory, process and work. For each measuring level, the management items are defined. This management items is going to be reference of the succeeding analyses.

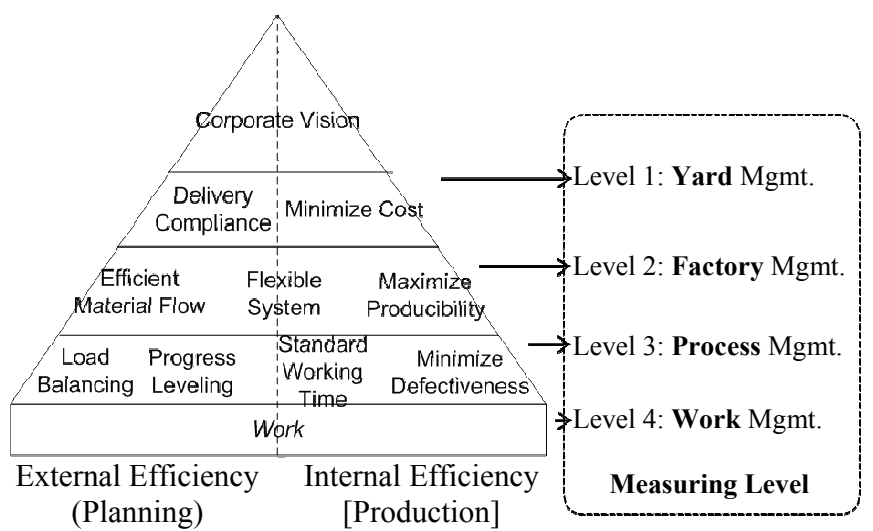

Competitiveness Index Pyramid of Production

Management

Fig. 7 Design of competitiveness index pyramid and corresponding measuring level for ship production management.

\section{Extraction of Critical Success Factor thru Value Driver Tree Analysis}

VDT analysis for the extraction of critical success factors is conducted based on the competitiveness index pyramid and the standard ship production management system. The completion of VDT analysis is until there will be no more 
detailed index, and the final node of the VDT is selected CSF for each measuring level of the competitiveness index pyramid from level 1 to level 3. However, the VDT analysis for level 4 is excluded in this paper because the management of the shop floor work is mainly managed by the shop floor manager, and this is beyond the scope of the ship production management system in practice. Fig. 8 shows a VDT analysis for the factory level and the process level, where the mechanism of CSF extraction for the factory and the process can be examined.

\section{Function Analysis thru KPI Analysis}

Strategic ship production management is available by defining KPIs from VDT result (CSFs) with respect to each target level defined at competitive index pyramid (Fig. 7). In this paper, KPI is defined according to following guidance referencing Balanced Score Card (BSC) template.

(1) Factors for execution of CSF

(2) Factors for management of CSF

(3) Estimation \& Validation Method for the CSF

According this guidance, upper connected category and strategy is defined firstly. Then, KPI and its matching CSF are connected with the relevant measuring unit and participation. This analysis is also conducted for level 1 , level 2 and level 3 of competitiveness index pyramid. Table 3 shows an analysis result of level 3 , that is process management level.

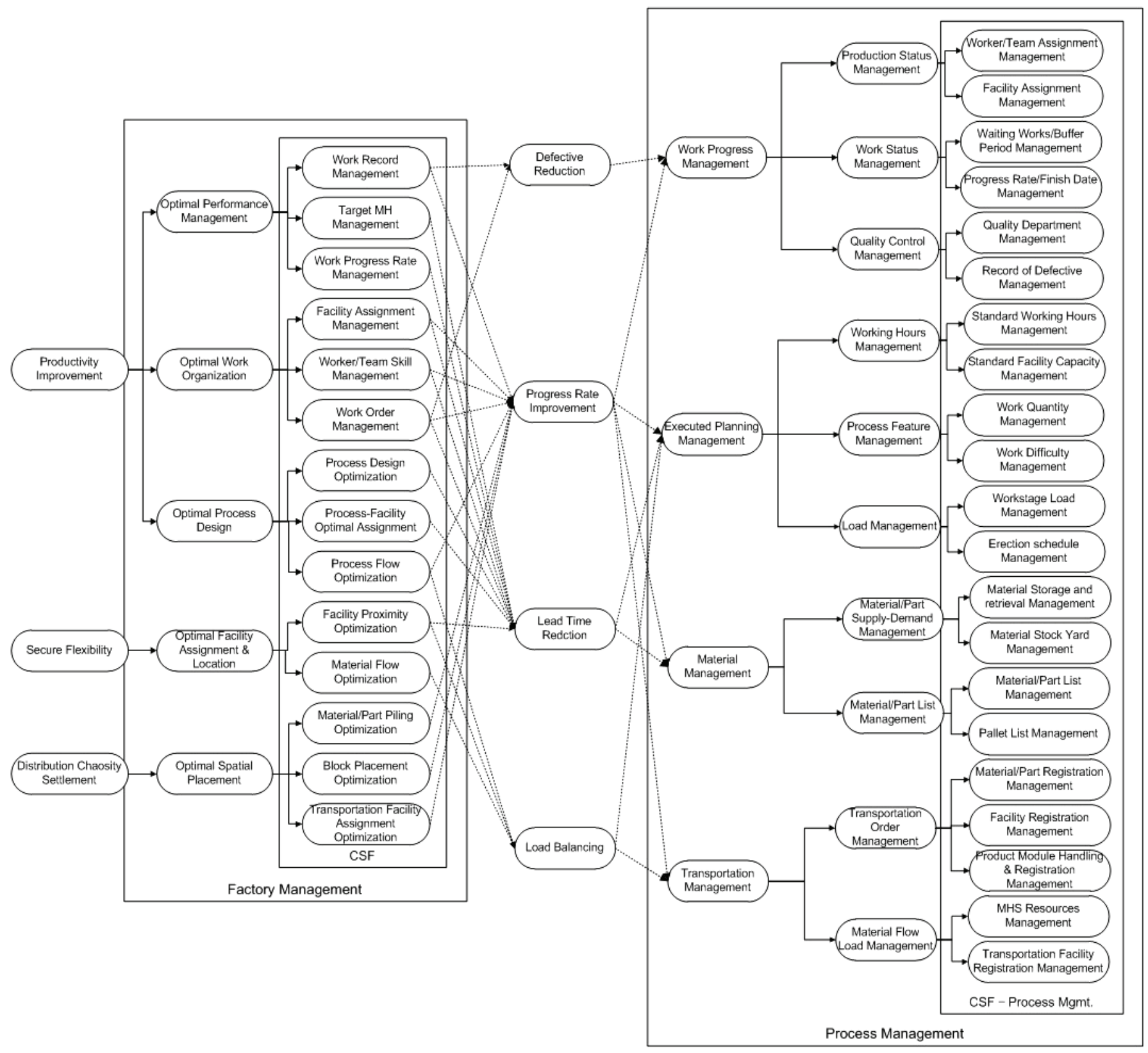

Fig. 8 VDT Analysis (Factory level and Process level). 
Table 3 BSC Analysis for Process Management Level.

\begin{tabular}{|c|c|c|c|c|c|c|}
\hline 1 & Process Management & $\begin{array}{l}\text { Defective reduction/ } \\
\text { Progress rate } \\
\text { observation }\end{array}$ & $\begin{array}{l}\text { Management of } \\
\text { worker/Team } \\
\text { assignment }\end{array}$ & $\begin{array}{l}\text { Required working hours/Planned production } \\
\text { lead time }\end{array}$ & $\begin{array}{l}\text { Normalized } \\
\text { working time }\end{array}$ & $\begin{array}{l}\text { Shop floor } \\
\text { manager }\end{array}$ \\
\hline 2 & Process Management & $\begin{array}{c}\text { Defective reduction/ } \\
\text { Progress rate observation }\end{array}$ & $\begin{array}{c}\text { Management of } \\
\text { facility assignment }\end{array}$ & $\begin{array}{l}\text { Required working hours w.r.t. facility/Planned lead } \\
\text { time (=Cycle time of assigned facility) }\end{array}$ & Cycle time & Shop floor manager \\
\hline 4 & Process Management & $\begin{array}{c}\text { Defective reduction/ } \\
\text { Progress rate observation }\end{array}$ & \begin{tabular}{|c|}
$\begin{array}{c}\text { Management of } \\
\text { progress } \\
\text { rate/Work finish } \\
\text { date }\end{array}$ \\
\end{tabular} & $\begin{array}{l}\text { Predicted work finish day (Start date }+ \text { Required } \\
\text { working hours/Average daily working hours) }\end{array}$ & Day & Shop floor manager \\
\hline 5 & Process Management & $\begin{array}{c}\text { Defective reduction/ } \\
\text { Progress rate observation }\end{array}$ & $\begin{array}{l}\text { Management of } \\
\text { quality control }\end{array}$ & Defective works/Relevant processes & Number & Shop floor manager \\
\hline 7 & Process Management & $\begin{array}{c}\text { Defective reduction/Lead } \\
\text { time reduction/Load } \\
\text { balancing }\end{array}$ & $\begin{array}{c}\text { Management of } \\
\text { standard working } \\
\text { hours }\end{array}$ & $\begin{array}{l}\text { Standard working hours of standard product } \\
\text { module for each production process }\end{array}$ & Working time & $\begin{array}{l}\text { Shop floor } \\
\text { manager/Office } \\
\text { manager }\end{array}$ \\
\hline 8 & Process Management & $\begin{array}{c}\text { Progress rate } \\
\text { observation/Lead time } \\
\text { reduction/Load balancing }\end{array}$ & $\begin{array}{l}\text { Management of } \\
\text { standard facility } \\
\text { capacity }\end{array}$ & $\begin{array}{l}\text { Standard resource capacity for each production } \\
\text { resource }\end{array}$ & Working time & $\begin{array}{l}\text { Shop floor } \\
\text { manager/Office } \\
\text { manager }\end{array}$ \\
\hline 9 & Process Management & $\begin{array}{c}\text { Progress rate } \\
\text { observation/Lead time } \\
\text { reduction/Load balancing }\end{array}$ & $\begin{array}{l}\text { Management of } \\
\text { work volume } \\
\text { (Quantity) }\end{array}$ & $\begin{array}{l}\text { Working hours of given work quantity for each } \\
\text { process }\end{array}$ & Working time & $\begin{array}{c}\text { Shop floor } \\
\text { manager/Office } \\
\text { manager }\end{array}$ \\
\hline 10 & Process Management & $\begin{array}{c}\text { Progress rate } \\
\text { observation/Lead time } \\
\text { reduction/Load balancing }\end{array}$ & $\begin{array}{l}\text { Management of } \\
\text { work difficulty }\end{array}$ & $\begin{array}{c}\text { Work coefficient of difficulty of given work for } \\
\text { each process }\end{array}$ & Work coefficient & $\begin{array}{l}\text { Shop floor } \\
\text { manager/Office } \\
\text { manager }\end{array}$ \\
\hline 14 & Process Management & $\begin{array}{l}\text { Progress rate } \\
\text { observation/Lead time } \\
\text { reduction }\end{array}$ & $\begin{array}{c}\text { Management of } \\
\text { material stock yard }\end{array}$ & $\begin{array}{l}\text { Check whether or not of information sheet of } \\
\text { material sock yard and material list }\end{array}$ & Info. sheet/List & $\begin{array}{l}\text { Shop floor } \\
\text { manager/Office } \\
\text { manager }\end{array}$ \\
\hline 15 & Process Management & $\begin{array}{c}\text { Progress rate } \\
\text { observation/Lead time } \\
\text { reduction }\end{array}$ & $\begin{array}{l}\text { Management of } \\
\text { material/part list }\end{array}$ & Check whether or not of material/part list & List & $\begin{array}{l}\text { Shop floor } \\
\text { manager/Office } \\
\text { manager }\end{array}$ \\
\hline 16 & Process Management & $\begin{array}{l}\text { Progress rate } \\
\text { observation/Lead time } \\
\text { reduction }\end{array}$ & $\begin{array}{l}\text { Management of } \\
\text { pallet list }\end{array}$ & Check whether or not of pallet list & List & $\begin{array}{c}\text { Shop floor } \\
\text { manager/Office } \\
\text { manager }\end{array}$ \\
\hline 17 & Process Management & $\begin{array}{l}\text { Progress rate } \\
\text { observation/Load } \\
\text { balancing }\end{array}$ & $\begin{array}{l}\text { Management of } \\
\text { material/part } \\
\text { registration }\end{array}$ & Check whether or not of material/part order sheet & Order sheet & $\begin{array}{l}\text { Shop floor } \\
\text { manager/Office } \\
\text { manager }\end{array}$ \\
\hline 18 & Process Management & $\begin{array}{c}\text { Progress rate } \\
\text { observation/Load } \\
\text { balancing }\end{array}$ & $\begin{array}{c}\text { Management of } \\
\text { facility registration }\end{array}$ & Check whether or not facility order shee & Order sheet & $\begin{array}{c}\text { Shop floor } \\
\text { manager/Office } \\
\text { manager }\end{array}$ \\
\hline 19 & Process Management & $\begin{array}{c}\text { Progress rate } \\
\text { observation/Load } \\
\text { balancing }\end{array}$ & \begin{tabular}{|} 
Management of \\
product module \\
handling, register
\end{tabular} & $\begin{array}{l}\text { Check whether or not product module list and } \\
\text { MHS order sheet }\end{array}$ & List/Order sheet & $\begin{array}{l}\text { Shop floor } \\
\text { manager/Office } \\
\text { manager }\end{array}$ \\
\hline 20 & Process Management & $\begin{array}{l}\text { Progress rate } \\
\text { observation/Load } \\
\text { balancing }\end{array}$ & $\begin{array}{l}\text { Management of } \\
\text { MHS resources }\end{array}$ & MHS resources utilization & Utilization & $\begin{array}{l}\text { Material handling } \\
\text { manager }\end{array}$ \\
\hline 21 & Process Management & $\begin{array}{c}\text { Progress rate } \\
\text { observation/Load } \\
\text { balancing }\end{array}$ & $\begin{array}{c}\text { Management of } \\
\text { transportation } \\
\text { facility registration }\end{array}$ & Order sheet of transportation registration & Order sheet & $\begin{array}{l}\text { Shop floor } \\
\text { manager/Office } \\
\text { manager }\end{array}$ \\
\hline
\end{tabular}




\section{INTEGRATION OF THE EXTRACTED FUNCTIONS AND ALGORITHMS WITH DIGITAL SHIPYARD}

Until now, preliminary research of digital shipyard has been focused on the modeling aspect based on the Plan-DoSee (PDS) cycle. The modeling aspect has been emphasized because the usersor customers of digital shipyard at the shipbuilding companies want to implement a detail model that is close to the actual physicalfactory or processes as far as possible.The strategic and tactical aspect, however, is being aroused with a movement of matter of concern into an execution platform as a virtual management, and the potential of digital shipyard meet with those needs. Accordingly, the directivity of digital shipyard is heading for the realization ofship production management.

In this paper, I'm going to suggest a way of converting previous digital shipyard method into a concept of virtual execution platform that can test various tactical scenarios, resolve the abrupt problems at the scene in order of priority and manage the production status at the yard, and also this inherit the objects previously defined, flexibility and agility.For this purpose, the digital shipyard has to be implementedas system that could execute function of ship production management system.

\section{Review of Digital Shipyard}

Traditional definition of digital shipyard is a computer model of shipyard facility and process with input of available scenarios for the purpose of problem solving and optimal planning(Shin et al., 2001).

Meanwhile, the digital shipyard as a virtual execution platform is implemented by use of Discrete Event System (DES) methodology as a running infra and Product, Process, Resource and Schedule (PPRS) as a unified information. This enables decision making and data generation for production planning \& scheduling, work load balancing, strategy planning, production method, etc. Fig. 9 shows a conceptual PPRS data modeling that combine product, process, resource and schedule data into a single data model. Each data entity is combined selectivelyas implementing data object fit for analysis target.

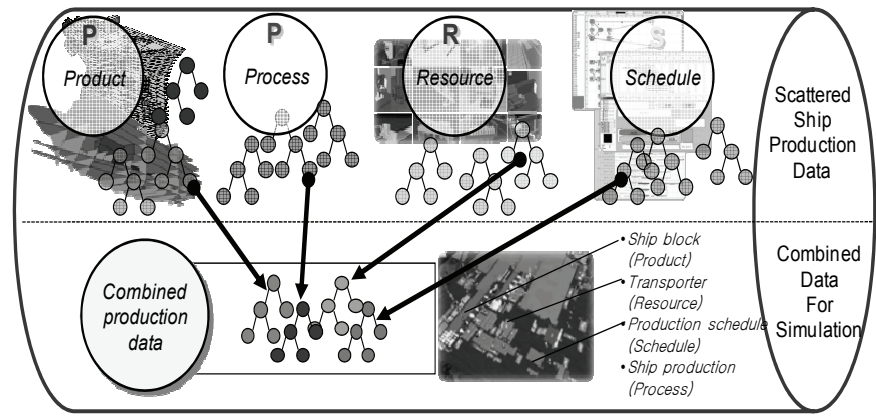

Fig. 9 Conceptual diagram of the integration of the PPRS information.

Table 4 Strategic Ship Production Management with Digital Shipyard.

\begin{tabular}{|c|c|c|c|}
\hline \multirow{2}{*}{ Management } & \multirow{2}{*}{ Description } & \multicolumn{2}{|c|}{ KPI Mapping } \\
\hline & & Measuring Level & KPI No. \\
\hline \multirow{2}{*}{$\begin{array}{l}\text { Planning } \\
\text { Information }\end{array}$} & \multirow{2}{*}{$\begin{array}{l}\text { Generate initial feasible planning master data and transfer to production } \\
\text { scheduling system }\end{array}$} & Yard & 2 \\
\hline & & Factory & $10,13,16$ \\
\hline \multirow[b]{2}{*}{ Load Balancing } & \multirow{2}{*}{$\begin{array}{l}\text { Improve planning quality in the view point of load balancing by applying } \\
\text { heuristic dispatching logic to digital shipyard model when production planning, } \\
\text { work assignment w/ resources are performed }\end{array}$} & Factory & 6 \\
\hline & & Process & $7,8,11,19,20,21$ \\
\hline \multirow{2}{*}{$\begin{array}{l}\text { Planning and } \\
\text { Scheduling }\end{array}$} & \multirow{2}{*}{$\begin{array}{l}\text { Minimize the planning and the scheduling error by investigating the result } \\
\text { preliminary in the virtual ship production environmentbefore release of } \\
\text { monthly or weekly work order }\end{array}$} & Yard & 2,12 \\
\hline & & Factory & $5,10,13,16$ \\
\hline $\begin{array}{l}\text { Strategy } \\
\text { Planning }\end{array}$ & $\begin{array}{l}\text { Deduce optimal enterprise planning strategy by running the long-term planning } \\
\text { information before release of final strategy } \rightarrow \text { Minimize enterprise risk w/ } \\
\text { resource operation, product mix, etc. }\end{array}$ & Yard & $2,12,14$ \\
\hline \multirow{3}{*}{$\begin{array}{l}\text { Progress Rate } \\
\text { Control }\end{array}$} & \multirow{3}{*}{$\begin{array}{l}\text { Improve accordance of planned progress rate and work record by combining S- } \\
\text { Curve method and virtual ship production environment }\end{array}$} & Yard & 2,11 \\
\hline & & Factory & 1,4 \\
\hline & & Process & $4,6,12,14$ \\
\hline \multirow{2}{*}{$\begin{array}{l}\text { Production } \\
\text { Method } \\
\text { Development }\end{array}$} & \multirow{2}{*}{$\begin{array}{l}\text { Impact Analysis of change or improvements of production methods, those } \\
\text { influence overall production processes }\end{array}$} & Yard & $9 \sim 14$ \\
\hline & & Factory & $8 \sim 13$ \\
\hline \multirow{3}{*}{$\begin{array}{l}\text { Process } \\
\text { Planning }\end{array}$} & \multirow{3}{*}{$\begin{array}{l}\text { Improve accordance between planning and execution by investigating the } \\
\text { process information and the specification of work order, finally optimize the } \\
\text { process routing }\end{array}$} & Yard & $5,10 \sim 14$ \\
\hline & & Factory & $5,6,8,10 \sim 12$ \\
\hline & & Process & $2,3,7,13$ \\
\hline \multirow{3}{*}{ Work Control } & \multirow{3}{*}{$\begin{array}{l}\text { Increase quality of work order at the shop floor applying heuristic dispatching } \\
\text { logic to digital shipyard model, that leads to an balanced work assignment to } \\
\text { workers and work group }\end{array}$} & Yard & 1 \\
\hline & & Factory & 5 \\
\hline & & Process & $1,8,10,13$ \\
\hline \multirow{2}{*}{$\begin{array}{l}\text { Execution } \\
\text { Planning }\end{array}$} & \multirow{2}{*}{$\begin{array}{l}\text { Generate executable planning information by simulating mid-term planning } \\
\text { scenario with work shop condition, facility assignment rule, work area } \\
\text { operation rule and worker and work group information }\end{array}$} & Factory & $1,4,10,11$ \\
\hline & & Process & 13,14 \\
\hline \multirow{3}{*}{$\begin{array}{l}\text { Material Flow } \\
\text { Control }\end{array}$} & \multirow{3}{*}{$\begin{array}{l}\text { Generate transportation schedule by input of production planning and } \\
\text { scheduling information (mainly mid-term scheduling) }\end{array}$} & Yard & $15 \sim 18$ \\
\hline & & Factory & $14 \sim 16$ \\
\hline & & Process & $14,15,15$ \\
\hline
\end{tabular}




\section{Strategy for Ship Production Management with Digital Shipyard}

In this chapter, a strategic approach will be introduced, that makes digital shipyard accept the requirements, which are functions of ship production management analyzed in the previous chapter. Actually these functions are core items derived as KPIs by connecting logically all the matters from competitiveness index pyramidvia value driver tree to balanced score card considering priority. These KPIs, in result, are going to be mainly focused managing point. Digital shipyard, ultimately for being virtual execution platform of ship production management, have to manage derived KPIs by implementing the product and the process flow in the production view point.

The target management processes of ship production management are selected for the practices of strategic digital shipyard as shown in left column of Table 4. Each target management processes is explained and mapped with the KPI of yard level, factory level and process level (Reference table for yard and factory measuring level is omitted in this paper). Namely, digital shipyard enables heuristic dealing of respective target management process by virtual execution. Heuristic, here, means that digital shipyard as virtual platform have functions and algorithms those operates with varying input of actual PPRS data, and finally validate input information or generate value added information.

Most use case of yard level is to virtualize ship block and heavy structure flow by considering factory, workstage, stockyard, dry dock, etc. The case of factory level is to virtualize critical object that require attentive treatmentby more detail modeling than case of yard level modeling. Similarly, individual production line, facility resource or work could be modeled. For example, such a cutting process, panel assembly process could be implemented into respective virtualized execution model for the plate/pallet management, the cycle time management, lead time management, work sequence management, etc.

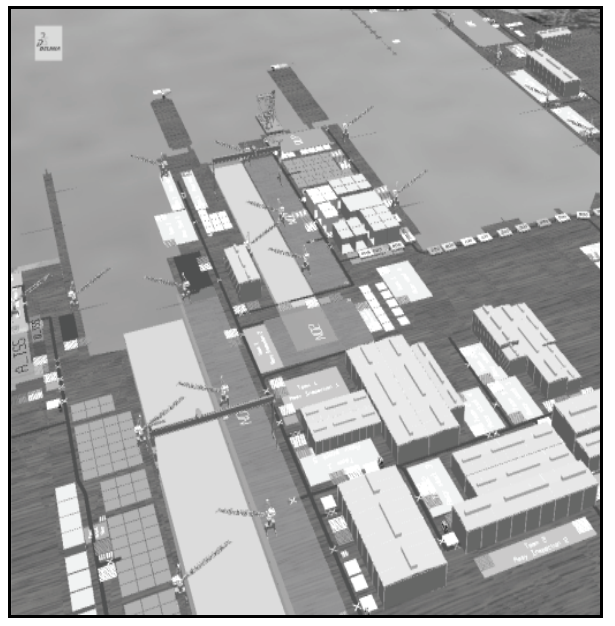

(a) Digital shipyard-Yard block logistics

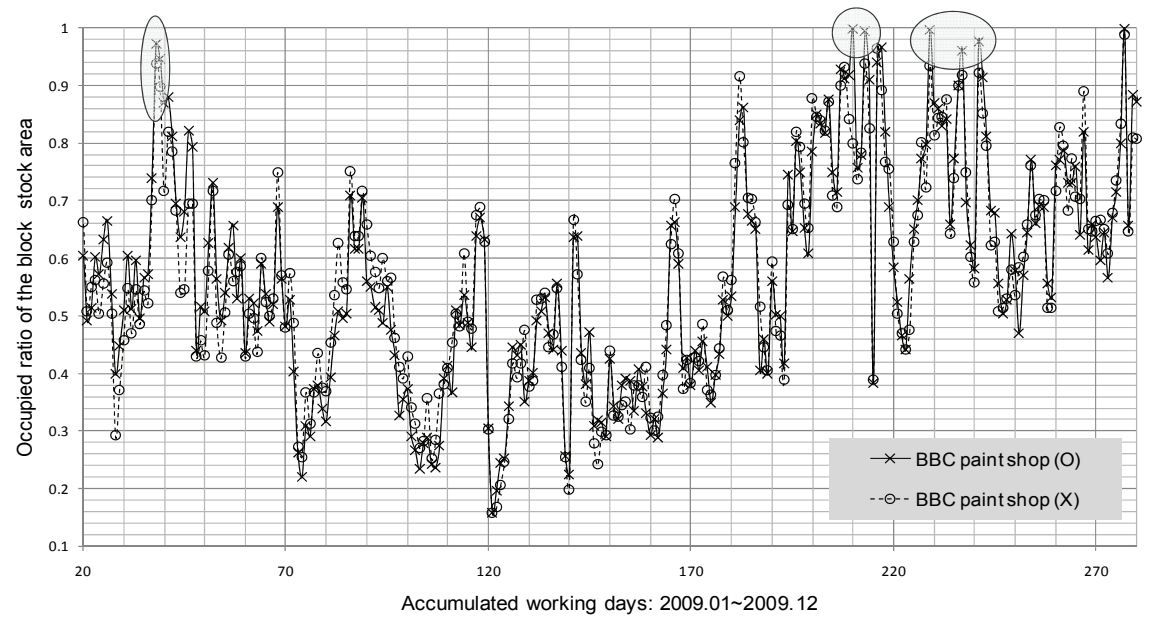

(b) Scenario comparison results

Fig. 10 Case study of simulation based platform for yard level management.

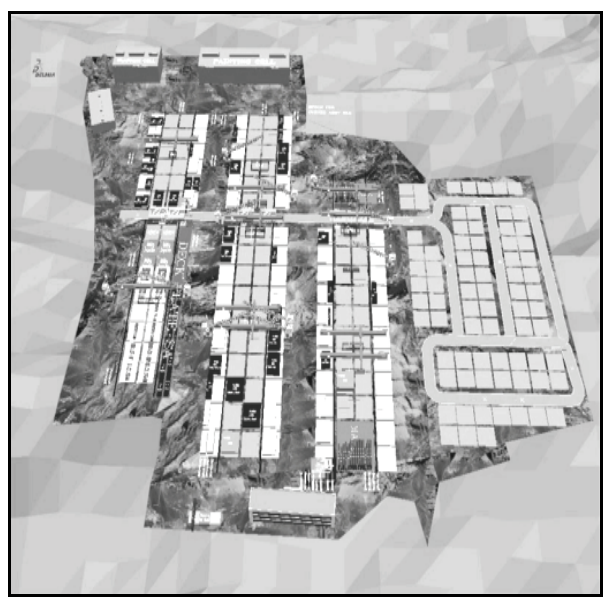

(a) Digital shipyard-Block assembly factory

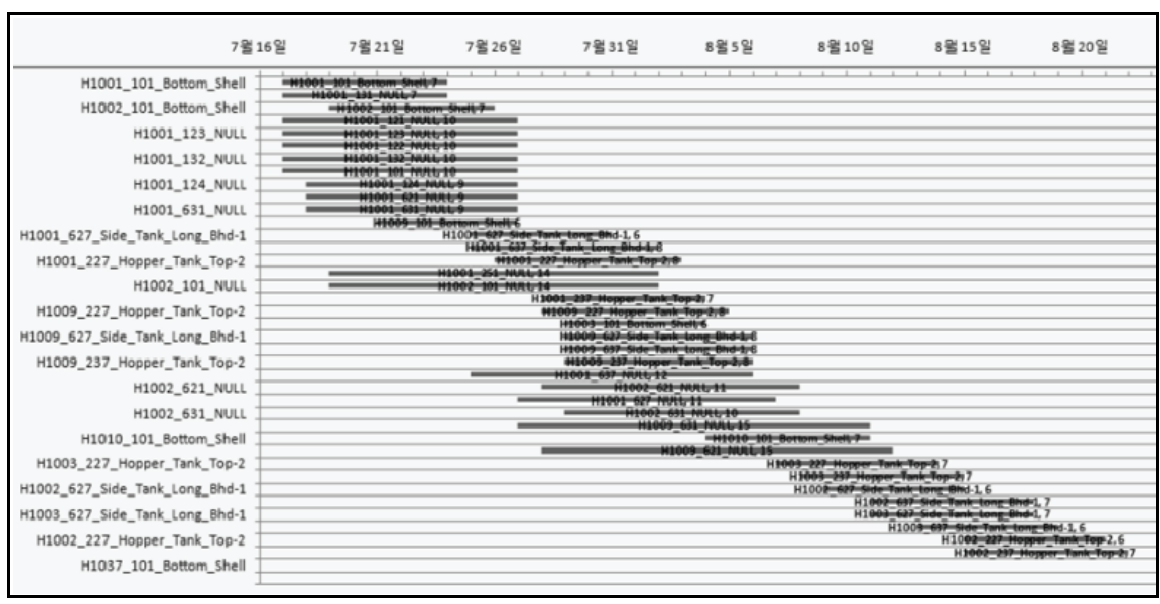

(b) Scheduling results

Fig. 11 Case study of simulation based platform for factory level management. 
As a digital shipyard case of yard level, Fig. 10 shows a block flow management. This digital model is being used for block flow planning, improvement scheme of block movement, and validation of layout change scenarios exploiting as virtual execution platform. In this case, all the factors that affect block flow in the yard such as production planning, workstage, stock area, transporter, etc. Also, as a digital shipyard case of factory level, Fig. 11 shows a block assembly factory that is being used for validation of midterm production planning and generation of execution scheduling data The left excel chart shows schedule calculated of each blocks considering the production availability and priority.

This approach enables enterprise ship production management by realizing actual product, process, resource and scheduling data into single entity, that overcometraditional static and discontinuous methodology of production management system. Eventually, digital shipyard is expected as a comprehensive computerized platform for virtual execution.

\section{CONCLUDING REMARKS}

Currently, the environment of the shipbuilding industry is getting complicated and the needs for the new product such as FPSO, FSRU are coming to fore. This paradigm shift emphasizes the agilityand flexibility.

In this paper, the standard shipbuilding production management system is proposed by investigating the environment of domestic major shipbuilding companies. Also, the research about the unified ship production management and the relevant system is conducted through detail analysis of the activities and the data flow of ship production management.

And, the system functions for the strategic approach of ship production management are investigated through the business administration tools such as performance pyramid, VDT and BSC. Lastly, the research of applying strategic KPI to the digital shipyard as virtual execution platform is conducted.

\section{REFERENCES}

Banks, R.L. and Wheel wright, S.C., 1979. Operations versus strategy-trading tomorrow for today. In:Harvard Business Review. Boston: In:Harvard Business School Press.

Betsy, M., 2006. Tearing up the Jack Welch playbook. In: Fortune.

Dixon, J.R. Nanni, A.J. and Vollman, T.El., 1990. The New Performance Challenge: Measuring, Operations for World-Class competition, Homewood, IL: Business One Irwin.
Goldraff, E. and Cox, J., 1986. Beating the Competition. In: The Goal, Hounslow: Creative Output Books.

Ittner, C.D. and Larcker, D.F., 1998. Innovations in Performance Measurement: Trends and Research Implications. Journal of Management Accounting Research, 10, pp.107-129.

Jack, W. and Suzy, W., 2005. Winning: HarperCollins.

Kaarsemaker, J. and Ubald, N., 2006. Simulation of $a$ maritime prefabrication process. In: Conference on Computer Applications and Information Technology in the Maritime Industries (COMPIT), Delft of Netherland.

Kaplan, R. and Norton, D., 1992. The Balanced ScorecardMeasures that Drive Performance. In: Harvard Business Review. Boston: Harvard Business School Press.

Lee, B.J., 2007. Creation Oriented Business Innovation Paradigm. In: LG Business Insight, LG: LG Economy Research Institute.

Lynch, R.L. and Cross, K.F., 1995. Measure up! Yard sticks for Continuous Improvement. $2^{\text {nd }}$ ed. Blackwell Business: Cambridge.

Neely, A., 1999. The Performance Measurement Revolution: Why Now and What Next?. International Journal of Operations and Production Management, 19(2), pp.205229.

Neely, D. Gregory, M. and Platts, K.A., 1995. Performance Measurement System Design-A Literature Review and Research Agenda, International Journal of Operations and Production Management, 15(4), pp.80-116.

Park, C., 1997. Comprehensive Organizational Performance Measurement System. In:Doctoral Dissertation. Columbia: University of Missouri.

Shin, J.G. Lee, J.H. Woo, J.H., 2001. Concept of Digital Shipbuilding. Journal of the Society of Naval Architects of Korea, 38(1), pp.54-62.

Skinner, W., 1971. The anachronistic factory. In:Harvard Business Review, Boston: Harvard Business School Press.

Skinner, W., 1974. The decline, fall, and renewal of manufacturing. In:Industrial Engineering.

Song, Y.J. Lee, K.K. Lee, D.G. Hwang, I.H. Woo, J.H. and Shin, J.G., 2008a. Development of Shipyard Layout Design Framework based on Simulation. Journal of the Society of Naval Architects of Korea, 45(2), pp.202212.

Song, Y.J. Lee, D.G. Woo, J.H. and Shin, J.G., 2008 b. Development of Shipyard Layout Design system based on Simulation. Journal of the Society of Naval Architects of Korea, 45(4), pp.441-454.

Steinhauer, D. and Stephanie, M.K., 2006. Simulation Aided Production Planning in Block Assembly. In: COMPIT(Conference on Computer Applications and Information Technology in the Maritime Industries), Delft of Netherland.

Woo, J.H., 2005. Modeling and Simulation of Indoor Shop System of Shipbuilding by Integration of the Product, Process, Resource and Schedule Information, Ph. D. Seoul National University Press. 